\title{
New Frontiers in Scientific Drilling of the Indian Ocean
}

\author{
by Stephen J. Gallagher, Neville Exon, Dhananjai Pandey, \\ S. Rajan, Mike Coffin, and Ken Takai
}

\section{Introduction}

The Indian Ocean exerts a fundamental control on the Earth's climate and hosts a variety of complex tectonic features. It influences the Indian Monsoon and hosts a major part of the thermohaline conveyor. It has been over a decade since scientific drilling occurred in the Indian Ocean, and as such there are major gaps in geoscientific understanding of this region. Future drilling of the sedimentary archives in the region will yield substantial information on the history of uplift, erosion, deposition and monsoonal history. It will improve our understanding of greenhouse/icehouse and ocean gateway dynamics and reef development. The region also hosts exceptional examples of Earth system processes and products that drilling will play an important role in illuminating. It would answer questions associated with subduction and tectonic plate breakup and reorganization. Major geodynamic issues to be investigated include hotspot/spreading ridge interactions and constraints on the mantle reference frame. There are many deep biosphere mysteries that may be solved by drilling sediment, such as the impact of Himalayan uplift and the monsoon on subseafloor community diversity. Drilling oceanic crust will reveal the nature of poorly known microbial communities at ridge systems, providing insights into the composition and abundance of microbial communities in different crustal provinces.

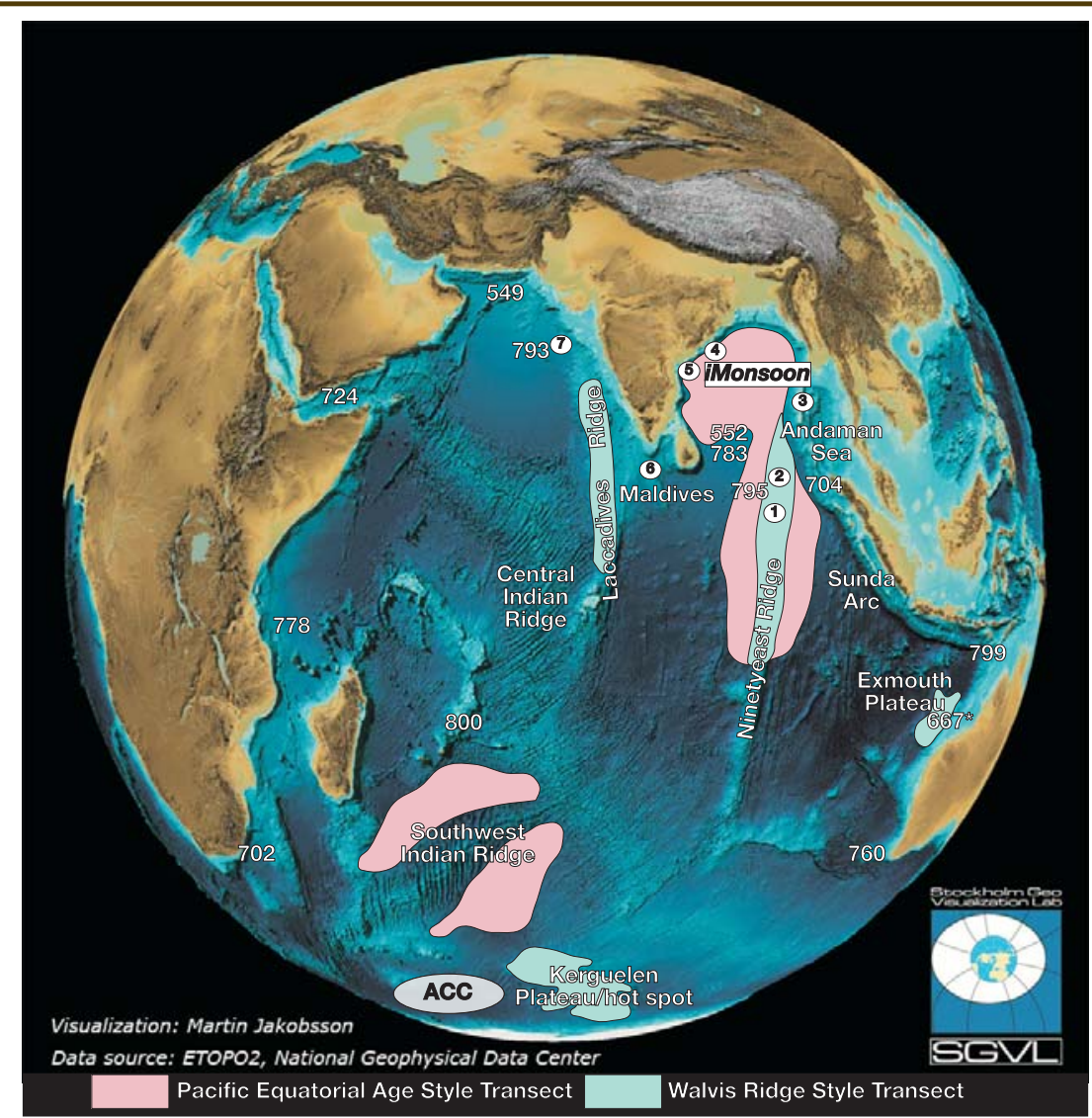

Figure 1. Pre-existing proposals and future drilling prospects in the Indian Ocean Potential Theme 1 targets include two types of deep ocean transects; ACC=Antarctic Circumpolar Current drifts proposal; Maldives atoll \& deep-water proposals. Theme 2 targets include iMonsoon program with locations: 1) DSDP 216, 2) ODP 758, 3) Andaman Sea, 4) Mahanadi Basin, 5) Krishna-Godavari Basin, 6) Cape Cormorin, and 7) Laxmi Basin Kerala-Konkan Basin. Theme 3 targets include most tectonic features shown. Theme 4 could be accommodated in most expeditions. Sourced from: http://www.gebco.net/general_ interest/bathymetry_visualisations.html

\section{Workshop Goals}

The Indian Ocean IODP Workshop was hosted in Goa in October 2011 by the National Centre for Antarctic and Ocean Research (NCAOR), India. The workshop was initiated and planned by Australian and Indian scientists to improve existing proposals (Table 1), build new proposals, and initiate alliances essential for drilling proposals.

The workshop was attended by seventy Indian and forty international scientists. Participants stressed the importance of the Indian Ocean in the planned new phase of drilling, the International Ocean Discovery Program (IODP, 2013-2023). The aim is to have several new proposals submitted in 2012 for drilling by 2014 or later, centered around global science problems discussed in four themes.

\section{Theme 1: Cenozoic Oceanography, Climate Change, Gateways and Reef Development}

Drilling Cenozoic marine sequences will lead to an enhanced understanding of Cretaceous to Paleogene ocean oxygenation; greenhouse to icehouse transitions; 
the history of the Indian Ocean Dipole; the Antarctic Circum-Polar (ACC) and Agulhas Currents (AC); the timing of the Indonesian Throughflow (ITF) and the origin of reefs. This theme addresses Challenges 1, 2 and 7 of IODP Science Plan 2013-2023. Three subthemes were discussed.

Evolution of the shallow carbonate environment. Prospective proposals will suggest deep and shallow drill sites in the Maldives Archipelago to better understanding the influence of the monsoon-generated current system and sea-level fluctuations on

Table 1. A list of the current active proposals in the Indian Ocean.

\begin{tabular}{|c|c|c|}
\hline Proposal & Short Title & Lead Proponent \\
\hline 549-Full-6 & Northern Arabian Sea Monsoon & Lückge, Germany \\
\hline 552-Add & Bengal Fan & France-Lanord, France \\
\hline 595-Full-4 & Indus Fan and Murray Ridge & Clift, U.K. \\
\hline 667-Full & NW Australian Shelf Eustasy & Fulthorpe, U.S.A. \\
\hline 702-Full & Southern African Climates & Zahn, Spain \\
\hline 704-Full-2 & Sumatra Seismogenic Zone & Goldfinger, U.S.A. \\
\hline 724-Full & Gulf of Aden Faunal Evolution & de Menocal, U.S.A. \\
\hline 760-Pre & SW Australia Margin Cretaceous Climate & Grocke, U.K. \\
\hline 778-Full-2 & Tanzania Margin Paleoclimate Transect & Wade, U.K. \\
\hline 783-APL & Indian Monsoon History & Hathorne, U.K. \\
\hline 793-СРP & Arabian Sea Monsoon & Pandey, India \\
\hline 795-Pre & Indian Monsoon Rainfall & Clemens, U.S.A. \\
\hline 799-Pre & West Pacific Warm Pool & Rosenthal, U.S.A. \\
\hline 800-Full & Indian Ridge Moho & Dick, U.S.A. \\
\hline
\end{tabular}

the Neogene development of the

Maldives platform (Betzler et al., 2009). Another potential proposal will address the origin of modern atolls and drowned flat top banks that have developed since the Pliocene.

Deep ocean record of palaeoceanography/climate. A series of transects ("Walvis Ridge Transects", Westerhold et al., 2007; "Pacific Equatorial Age Transects”, Lyle et al., 2010; Fig. 1) were suggested to reveal the long-term history of palaeo- $\mathrm{CO}_{2}$ levels, sea surface temperatures, ocean anoxic events and the Indian Ocean Dipole. Several proposals focusing on recovering deep oceanic and climatic Cretaceous to Neogene records (proposals 760-Pre, 724-Full and 778-Full) have been submitted.

Ocean margin boundary currents and gateways. The ITF and ACC are key drivers of global climate. Understanding the response of these currents to glacio-eustatic and tectonic triggers will allow us to predict their behavior in the future in the context of global climate change. A new version of proposal 667-Full will be submitted in 2012 to investigate ITF and Leeuwin Current history (Gallagher et al., 2009). Another proposal will target ACC history (Barker and Thomas, 2004) by drilling the Conrad Rise. Proposal 702- Full will investigate AC history.

\section{Theme 2: The History of the Monsoons}

The Indian monsoonal circulation is the largest atmospheric transport system on Earth, including latent heat (moisture) sources in the southern Indian Ocean, crossequatorial transport with large-scale convergence and precipitation over the Indian and Southeast Asian regions, and influencing some three billion people seasonally. This circulation system is complex, driven by cross-equatorial pressure gradients dictated by changes in the Siberian High (winter monsoon), Indo-Asian low (summer monsoon) and both summer- and winter-season changes in the Mascarene
High of the southern subtropical Indian Ocean. The magnitude and regularity of the cross-equatorial flow make the Indian monsoon unique. Monsoonal circulation is dynamic on various time scales, from weekly to annual to decadal and linked to short time scale ocean-atmosphere interactions, to millions of years associated with regional and large-scale tectonism. Monsoon runoff from the continent has built the two largest fan systems on Earth, the Indus and Bengal Fans. These host a record of potentially high resolution of the history of uplift, erosion, deposition, and carbon burial. An understanding of the mechanisms driving monsoon climate changes at different time scales has high societal importance. Theme 2 addresses Challenges 1, 3-7, 11 and 13 of the IODP Scientific Plan.

Monsoonal Paleoclimate and Paleoceanography (MPP). This focused on the pelagic and hemipelagic archives as recorders of the local and regional responses to monsoon winds and precipitation (Clift and Molnar, 2003). This includes existing proposals 549 Full and 783 APL. The MPP subgroup recommend a workshop to produce a new proposal iMonsoon (Fig. 1) in time for consideration by the program panels and drilling by 2014 or soon after.

Sedimentary source-to-sink studies, using submarine fan (SF) archives. Submarine fans are recorders of long-term changes in erosion, transport and deposition linked to tectonics and climate change principally in the Himalayas (Clift et al., 2008; Gupta et al., 2011). These topics are included in proposals 609-Pre, 552-Full and 552-Add, 595-Full and 776- Full targeting the eastern and western river systems. However, amending these proposals with more proximal sites on each fan would allow the transport history to be better constrained. In this regard, the SF sub-committee also recommended a workshop on geohazards in the northern Bay of Bengal, focusing on the frequency of tropical cyclones, Holocene earthquakes, Pleistocene subsidence, and changing sediment supply due to deforestation and agriculture. 


\section{Theme 3: Tectonics and Volcanism}

The Indian Ocean hosts exceptional examples of Earth system processes and products that ocean drilling will play a key role in illuminating. Tectonic and magmatic objectives address Challenges 12 and 13 of the IODP Science Plan. Tectonic problems include those associated with; 1) subduction-fault properties and slip, sediment effects, role of fluids, segmentation, rupture, tsunamigenesis-along the Sunda arc, site of the great 2004 Indian Ocean earthquake (Gulick et al., 2011) and tsunami (Fig. 2) (proposal 704-Full-2: "Sumatra

Seismogenic Zone”); 2) tectonic plate breakup and reorganization associated with Kerguelen and Réunion hotspot activity; 3) India-Madagascar and India Seychelles break-up, origin and evolution of Laxmi and Laccadive ridges and intraplate deformation; and 4) possible incipient plate breakup along the Ninetyeast Ridge. Major geodynamic issues comprise hotspot-spreading ridge interactions and hotspot constraints on the mantle reference frame. Key geochemical questions include those associated with hotspotsAfar, Kerguelen, Réunion-that have sampled nearly the entire scope of mantle source compositions; 1) back-arc spreading magmatism, hydrothermal activity, mineralization, metallogenesis, and biosphere; 2) the testing of existing and development of new models for flood magmatism; 3) the origin and alteration of oceanic core complexes; and 4) the nature of the lower crust and Moho at slower spreading ridges (proposal 800-Full).

\section{Theme 4: The Deep Biosphere}

Scientific drilling has revealed the existence of a deep biosphere in surface and deep subsurface sediment and rocks (Roussel et al., 2008; Edwards et al., 2012). This biosphere is widespread, with some geological and geographical autochthonism, is genetically and geochemically diverse, and comprises a significant fraction of Earth's total living biomass (Orcutt et al., 2011). High temperatures and pressures, variable $\mathrm{pH}$ and salinity conditions, and insufficient access to nutrients, carbon, or energy are potential limiting factors for life in the deep subsurface (Takai and Nakamura, 2011). This theme addresses Challenges 5-7 of the IODP Science Plan.
Several geomicrobiological questions were identified that may be answered by drilling of Indian Ocean sediment. How has uplift of the Himalayas and the monsoon impacted the development of the deep biosphere since the Oligocene? How has the drainage from the Himalayan rivers influenced subseafloor community diversity? How has the subseafloor biosphere been inoculated with terrestrial microorganisms? Are there differences between the Bay of Bengal and Arabian Sea? How are the ecosystems related to the formation of ferromanganese nodules?

Other questions may be answered by drilling Indian Ocean Crust. What is the diversity and biogeography of communities in the very heterogeneous ridge systems? Which microbial communities and functions exist in different crustal provinces and structures? How are they related to hydrogeology and to the alteration of the crust?

In the future, these questions may be addressed if deep biosphere research is incorporated in existing IODP proposals. The community is looking for opportunities to join expeditions conducted by themes 1-3 (above) and to expand objectives by requesting coring through Ancillary Project Letters.

\section{Acknowledgements}

We thank IODP-MI, Ministry of Earth Sciences, India (MoES) and NCAOR, U.S. Science Support Program (USSSP), Australian and New Zealand IODP Consortium (ANZIC), and Japan Drilling Earth Science Consortium (J-DESC) for their funding support. We also thank the work- 
shop participants for their contribution to the success of this workshop.

\section{References}

Barker, P.F., and Thomas, E., 2004. Origin, signature and palaeoclimatic influence of the Antarctic Circumpolar Current. Earth Sci. Rev., 66:143-162, doi:10.1016/j.earscirev.2003.10.003

Betzler, C., Hübscher, C., Lindhorst, S., Reijmer, J.J.G., Römer, C.M., Droxler, A.W., Fürstenau, J., and Lüdmann, T., 2009. Monsoon-induced partial carbonate platform drowning (Maldives, Indian Ocean). Geology, 37:867-870, doi:10.1130/ G25702A.1

Clift, P., and Molnar, P., 2003. Scientific drilling of the Indian Ocean submarine fans: A report on the JOI/USSAC workshop for future IODP drilling. 23-25th July 2003, Boulder, CO (University of Colorado).

Clift, P.D., Hodges, K.V., Heslop, D., Hannigan, R., Long, H.V., and Calvès, G., 2008. Correlation of Himalayan exhumation rates and Asian monsoon intensity. Nature Geosci., 1:875-880.

Edwards, K.J., Becker, K., and Colwell, F., 2012. The deep, dark, energy biosphere. Ann. Rev. Earth Planet. Sci., 40:551-568.

Gallagher, S.J., Wallace, M.W., Li, C.L., Kinna, B., Bye, J.A.T, Akimoto, K., and Torii, M., 2009. Neogene history of the Indo-Pacific Warm Pool, Kuroshio and Leeuwin currents. Paleoceanography, 24:PA1206, doi:10.1029/2008PA001660

Gulick, S.P.S., Austin, Jr, J.A., McNeill, L.C., Bangs, N.L.B., Martin, K.M., Henstock, T.J., Bull, J.M., Dean, S., Djajadihardja, Y.S., and Permana, H., 2011. Updip rupture of the 2004 Sumatra earthquake extended by thick indurated sediments. Nature Geosci., 4:453-456.

Gupta, A.K., Mohan, K., Sarkar, S., Clemens, S.C., Ravindra, R., and Uttam, R.K., 2011. East-West similarities and differences in the surface and deep northern Arabian Sea records during the past 21 Kyrs. Palaeogeogr. Palaeoclimatol. Palaeoecol., 301:75-85.

Lyle, M., Pälike, H., Nishi, H., Raffi, I., Gamage, K., Klaus, A., and the IODP Expeditions 320/321 Scientific Party, 2010. The Pacific equatorial age transect, IODP Expeditions 320 and 321: Building a 50-million-year-long environmental record of the equatorial Pacific. Sci. Drill., 9:4-15, doi:10.2204/ iodp.sd.9.01.2010.

Orcutt, B.N., Sylvan, J.B., Kanb, N.J., and Edwards, K.J., 2011. Microbial ecology of the dark ocean above, at, and below the seafloor. Microbiol. Mol. Biol. Rev., 75:361-422, doi: 10.1128/MMBR.00039-10.

Roussel, E.G., Bonavita, M.-A.C., Querellou, J., Cragg, B.A., Webster, G., Prieur, D., and Parkes, R.J., 2008. Extending the subsea-floor biosphere. Science, 320(5879):1046, doi: 10.1126/ science.1154545.

Takai, K., and Nakamura, K., 2011. Limits of life and the biosphere: Lessons from deep subsurface of the Earth. In Gargaud, M., Lopez-Garcia, P., and Martin, H. (Eds.), Origins and Evolution of Life: New York (Cambridge University Press), 469-486.
Westerhold, T., Rohl, U., Laskar, J., Raffi, I., Bowles, J., Lourens, L.J., and Zachos, J.C., 2007. On the duration of magnetochrons $\mathrm{C} 24 \mathrm{r}$ and $\mathrm{C} 25 \mathrm{n}$ and the timing of early Eocene global warming events: Implications from the Ocean Drilling Program Leg 208 Walvis Ridge depth transect. Paleoceanography, 22:PA2201, doi:10.1029/2006PA001322

\section{Authors}

Stephen J. Gallagher, The School of Earth Sciences, The University of Melbourne, Victoria 3010, Australia, e-mail: sjgall@unimelb.edu.au

Neville Exon, Research School of Earth Sciences, Australian National University, Canberra 0200, Australia, e-mail: Neville.Exon@anu.edu.au

Dhananjai Pandey and S. Rajan, National Centre for Antarctic and Ocean Research (NCAOR), Vasco da Gama, Goa, India, e-mail: dhananjai@gmail.com and rajan@ncaor. org

Mike Coffin, Institute for Marine and Antarctic Studies, University of Tasmania, Private Bag 129,HOBART, TAS 7001, Australia, e-mail: Mike.Coffin@utas.edu.au

Ken Takai, Subsurface Geobiology Advanced Research (SUGAR) Project, Japan Agency for Marine-Earth Science \& Technology (JAMSTEC), 2-15 Natsushima-cho, Yokosuka 237-0061, Japan, e-mail: kent@jamstec.go.jp

\section{Related Web Links}

http://www.ncaor.gov.in/IODP/index.html http://www.iodp.org/workshops/http://www.ncaor.gov.in/ IODP/index.html http://www.iodp.org/Science-Plan-for-2013-2023/ 